University of Nebraska - Lincoln

DigitalCommons@University of Nebraska - Lincoln

1989

\title{
Carbon Dioxide, Water Vapor and Sensible Heat Fluxes over a Tallgrass Prairie
}

S. B. Verma

University of Nebraska - Lincoln

Follow this and additional works at: https://digitalcommons.unl.edu/natrespapers

Part of the Natural Resources and Conservation Commons, Natural Resources Management and Policy Commons, and the Other Environmental Sciences Commons

Verma, S. B., "Carbon Dioxide, Water Vapor and Sensible Heat Fluxes over a Tallgrass Prairie" (1989). Papers in Natural Resources. 1203.

https://digitalcommons.unl.edu/natrespapers/1203

This Article is brought to you for free and open access by the Natural Resources, School of at DigitalCommons@University of Nebraska - Lincoln. It has been accepted for inclusion in Papers in Natural Resources by an authorized administrator of DigitalCommons@University of Nebraska - Lincoln. 


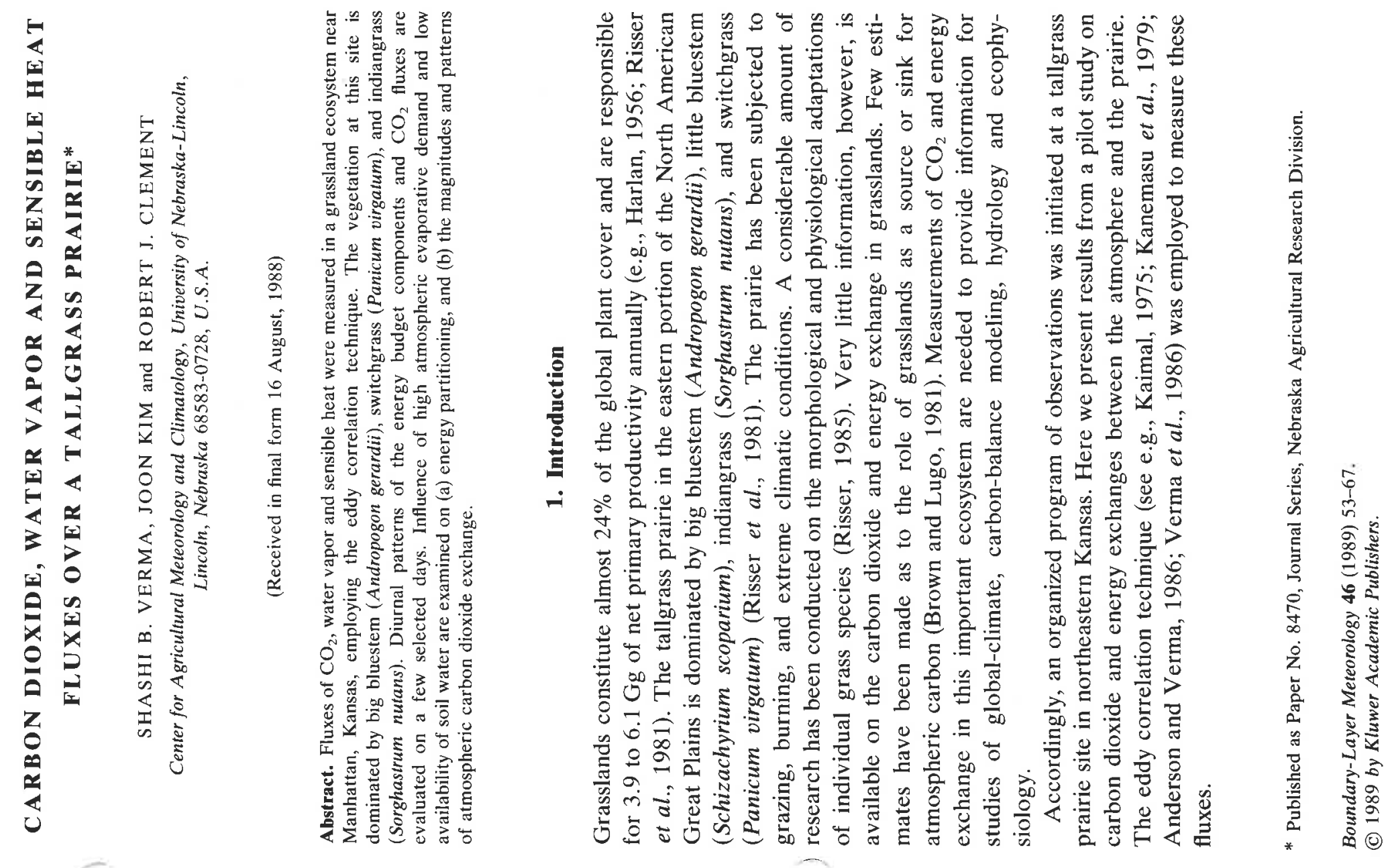




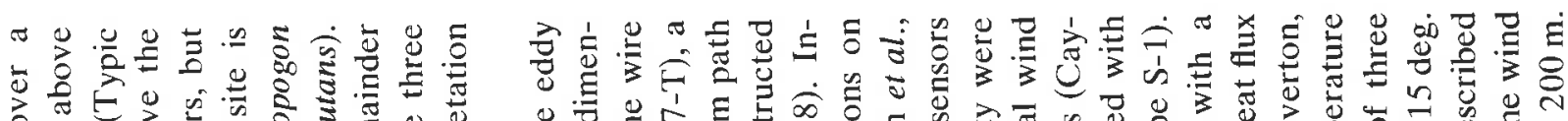

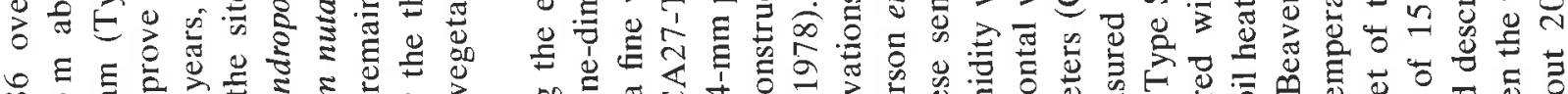

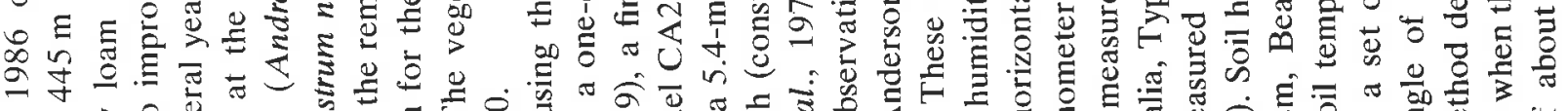
thes

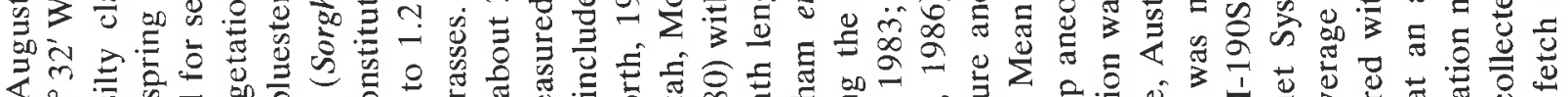

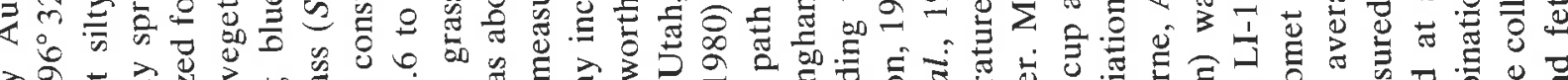

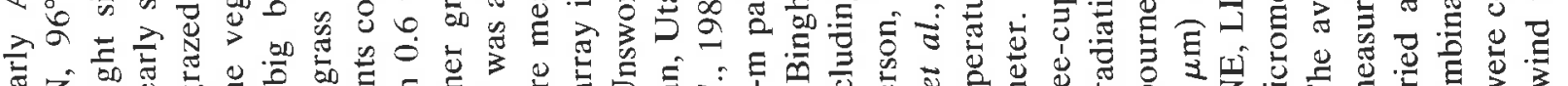

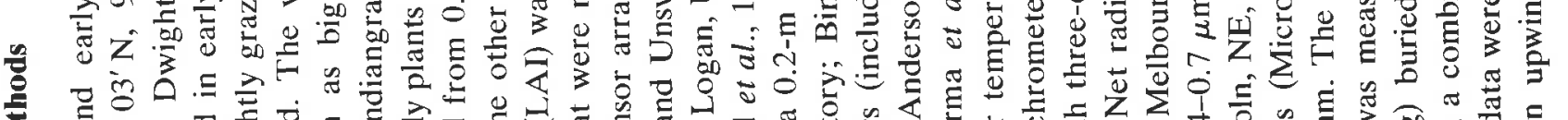

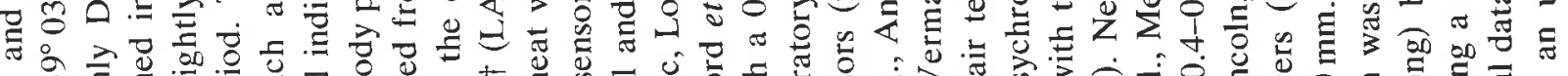

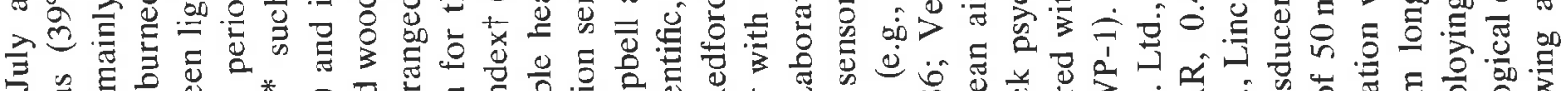

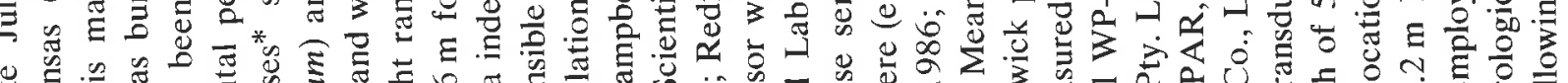

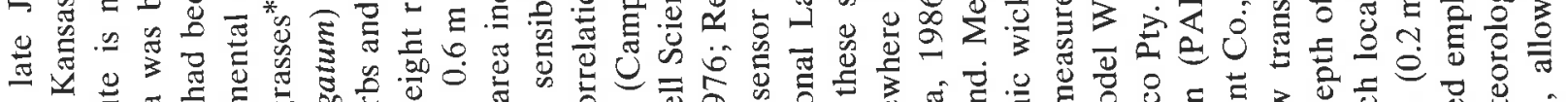

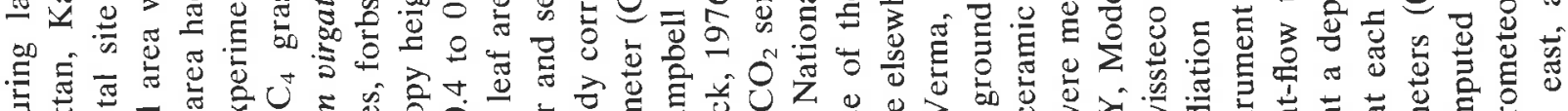

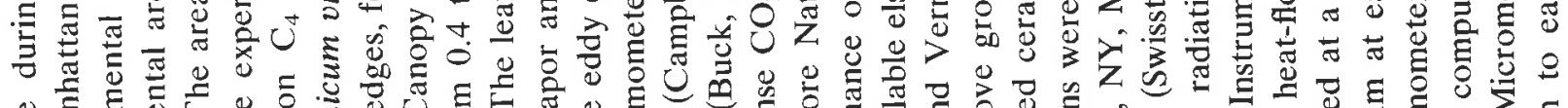

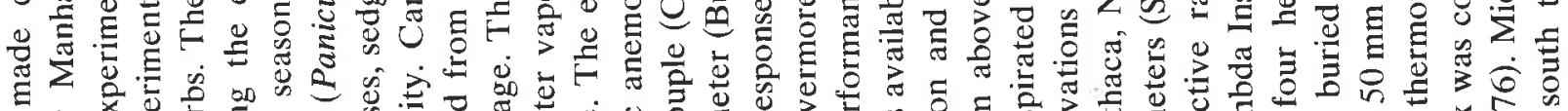

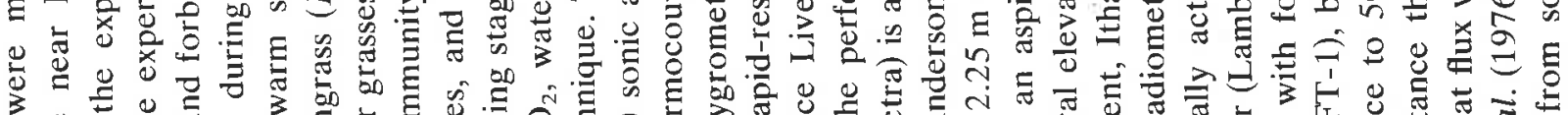

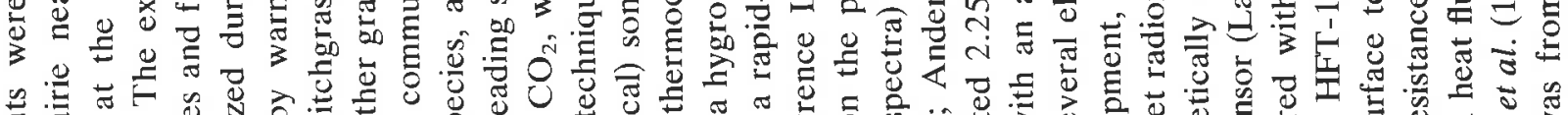

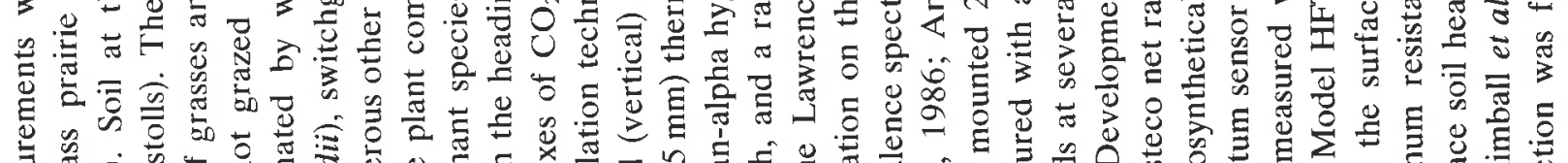

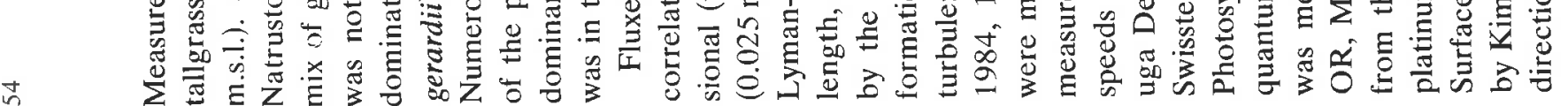

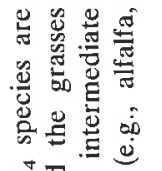

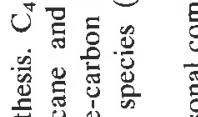

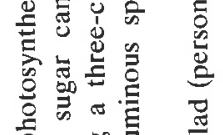

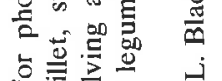

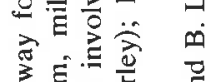

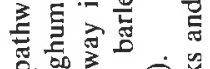

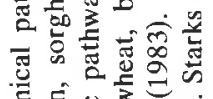

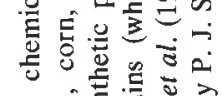
공 $\frac{2}{2}$

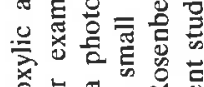
氙 F

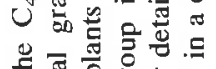

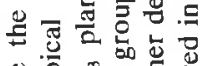

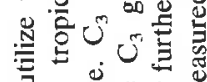
政

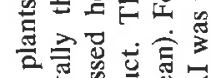

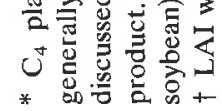


Ð

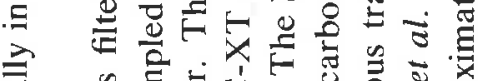
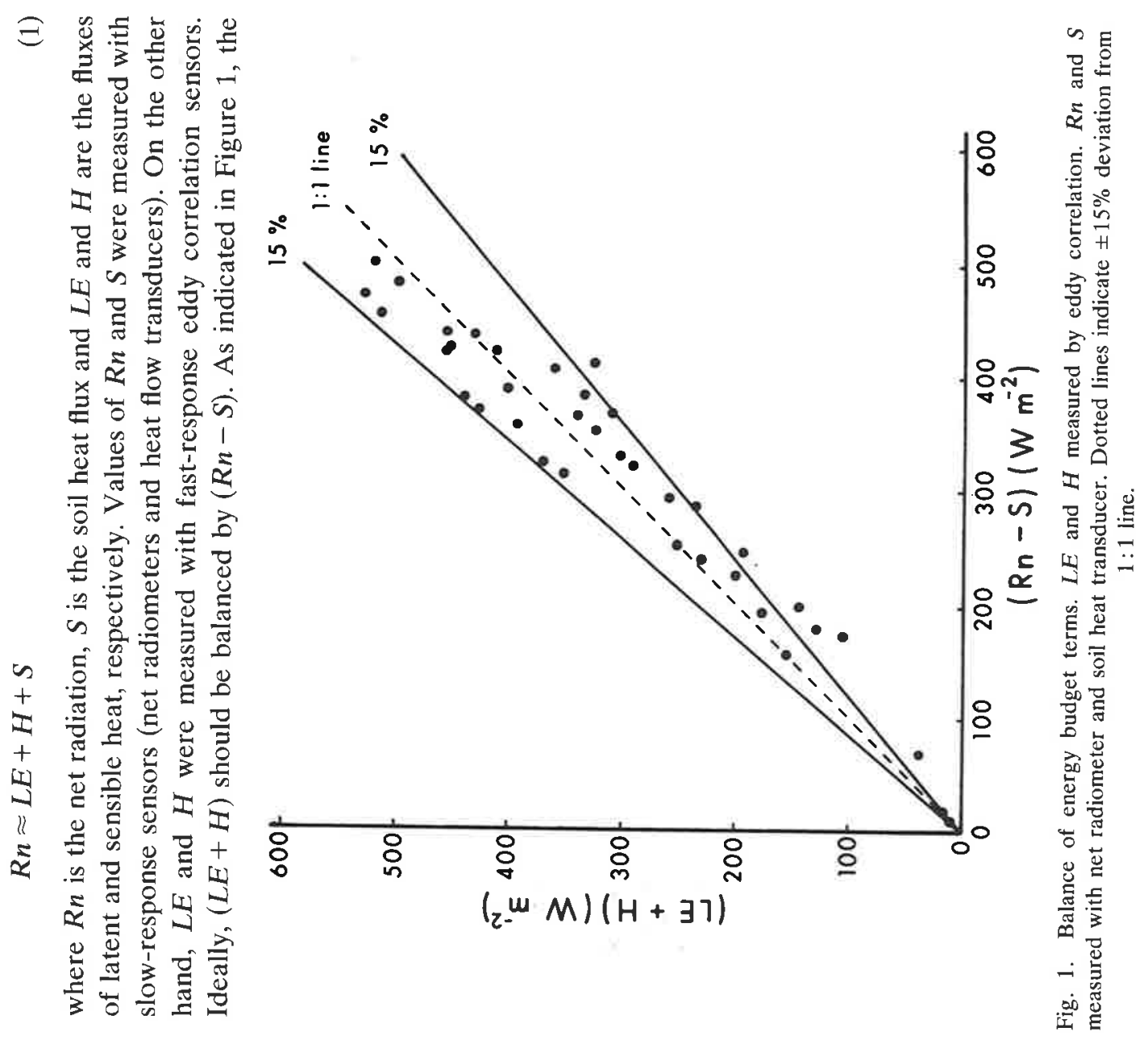


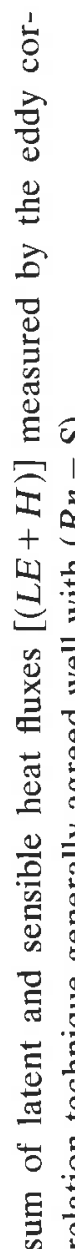

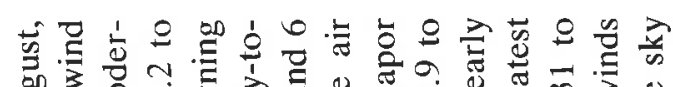

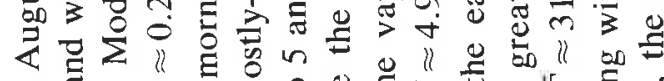

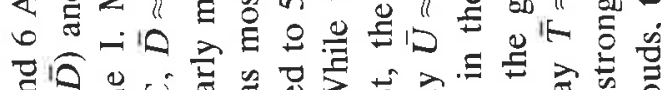

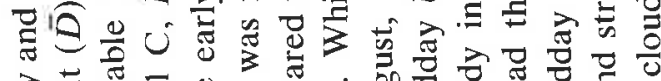

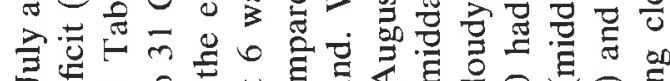

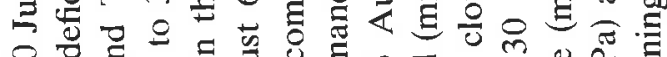

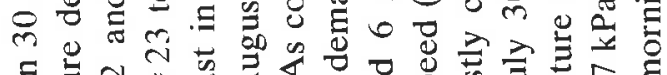

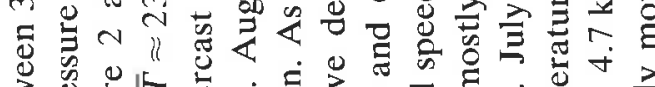

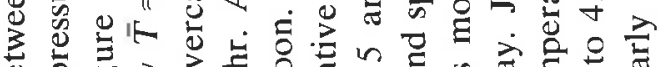

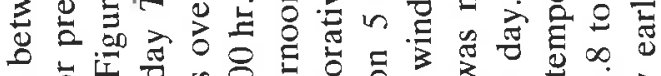

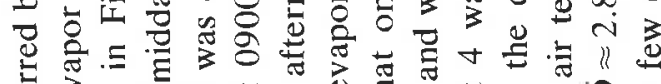

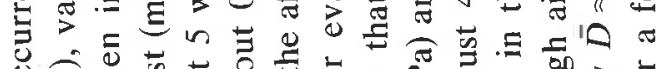

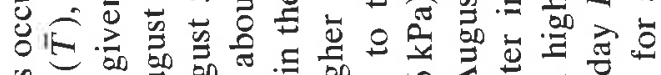

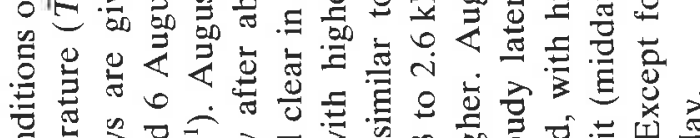

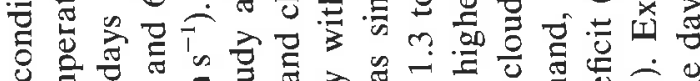

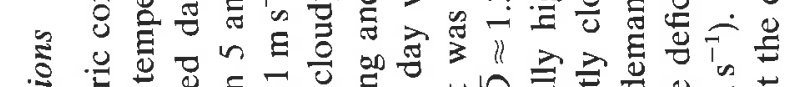

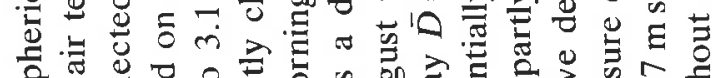
\%ั0

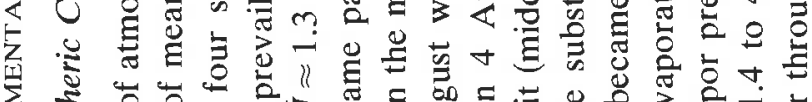

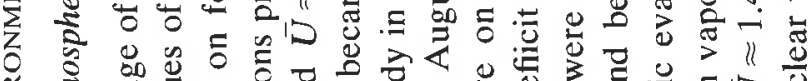

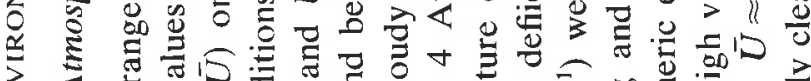

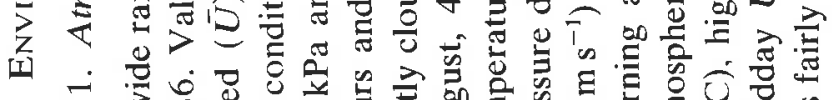
i -

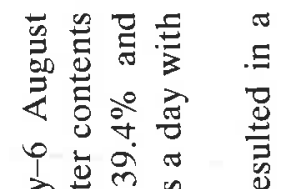

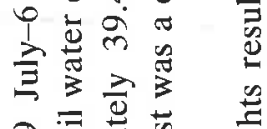

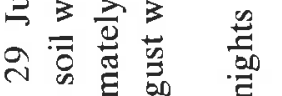

$\infty$. 을

吾总言

उ

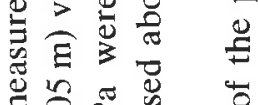

है

Eิ을

巳一

语焉焉 可可

ڤั

的定导吉 次管 证六家

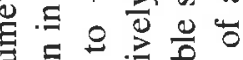
> पे क ज त

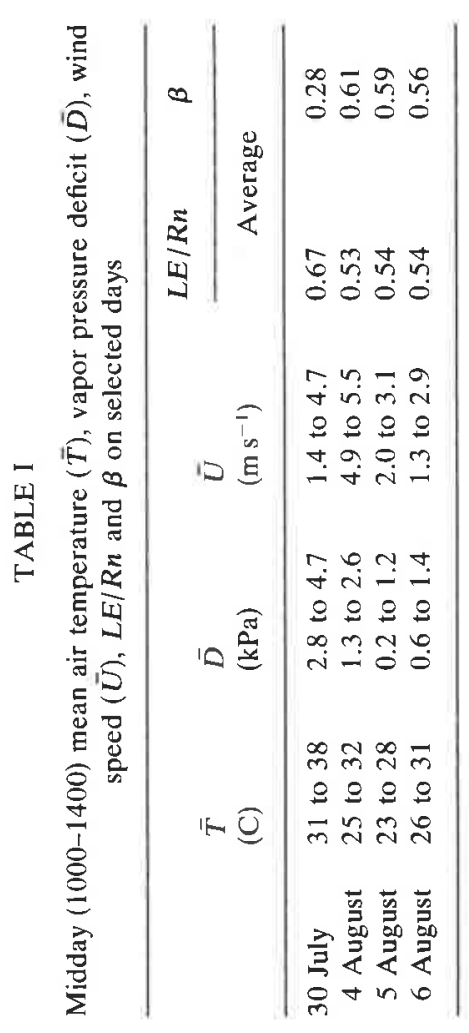
范 


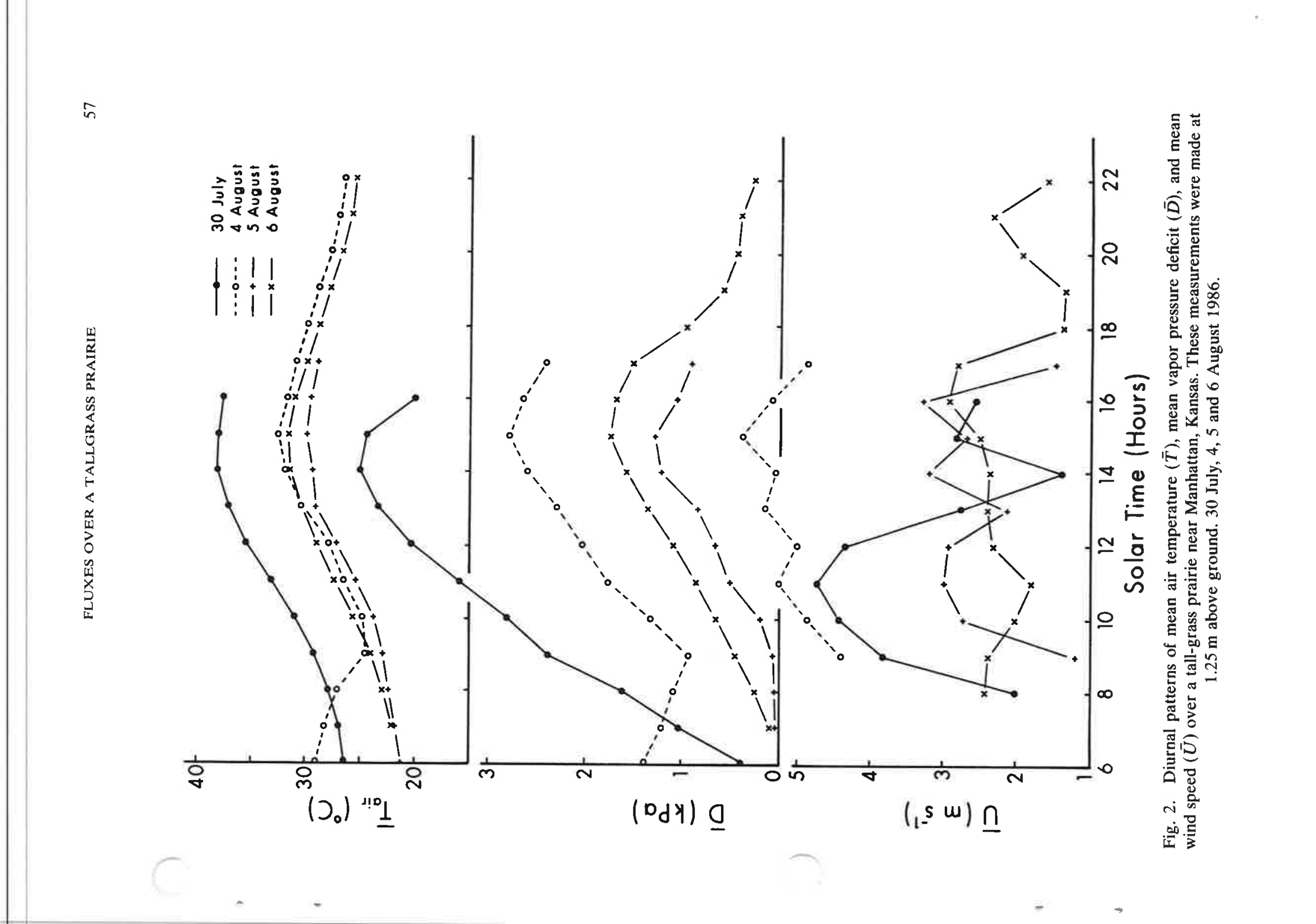




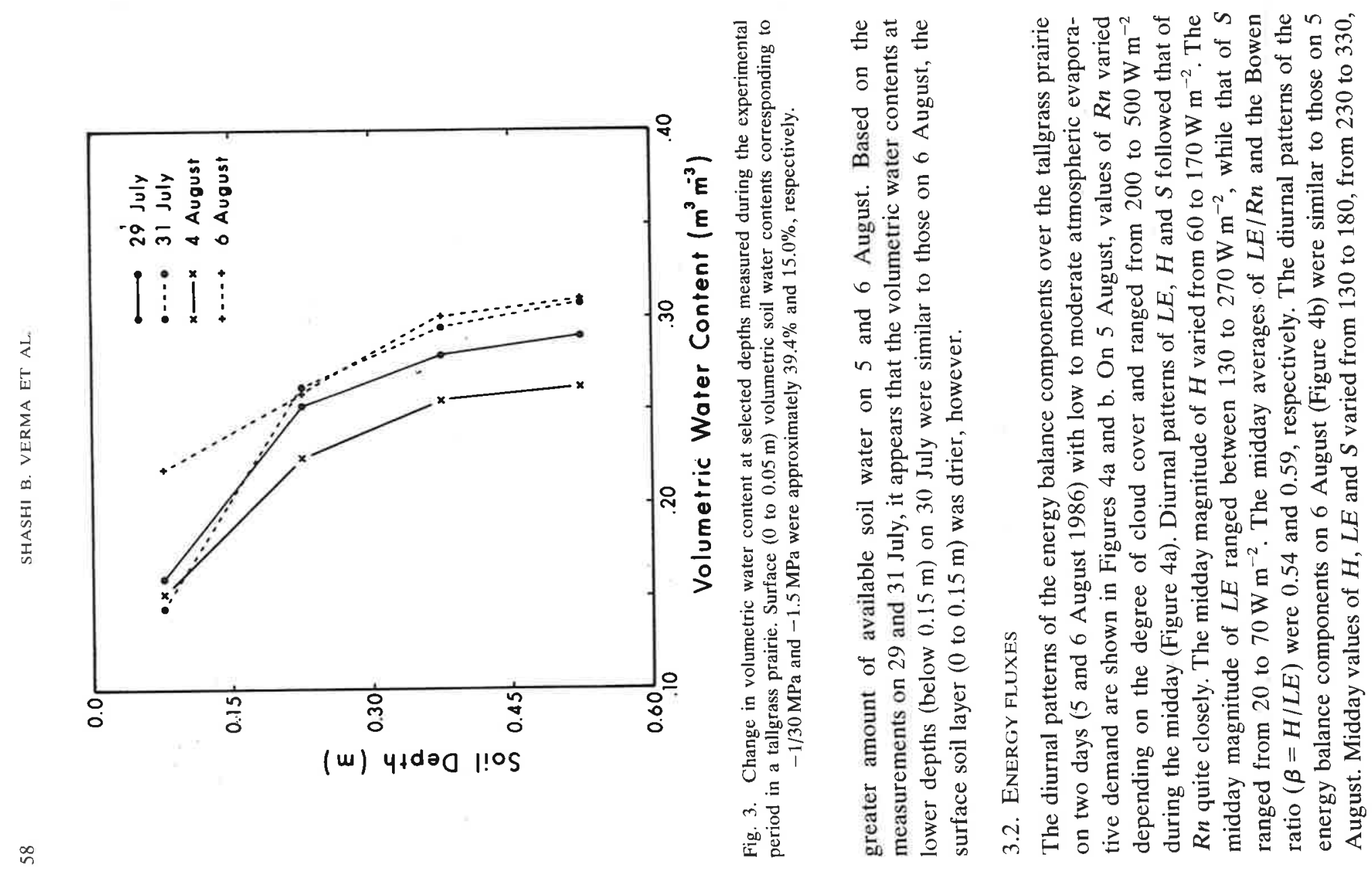




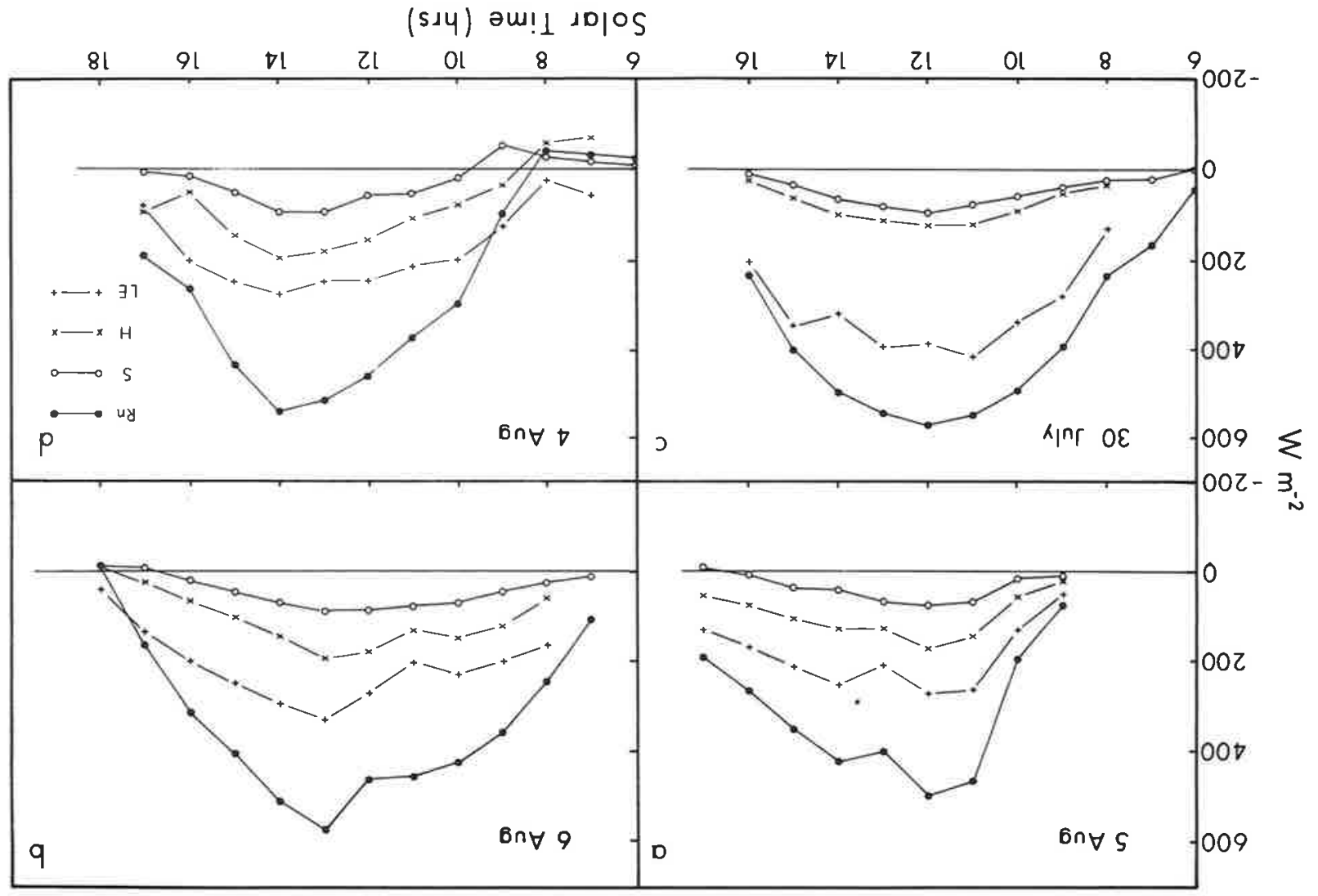




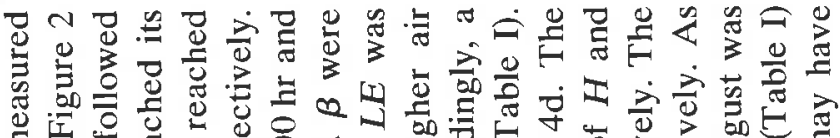
ह

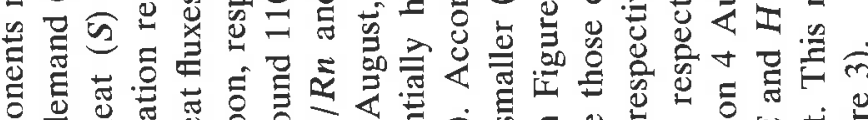

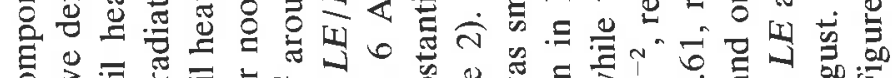

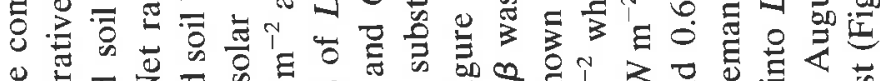

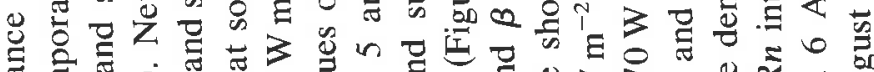

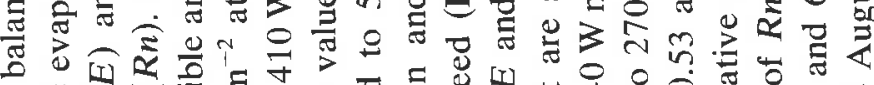

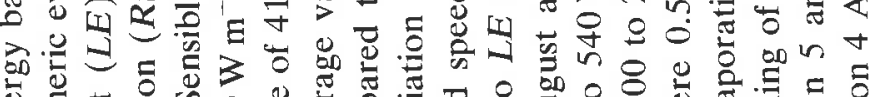
屯ี

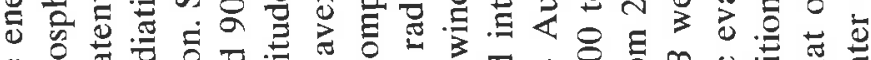

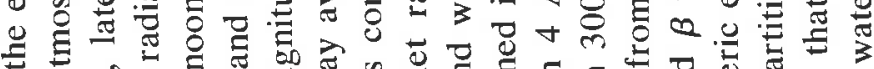

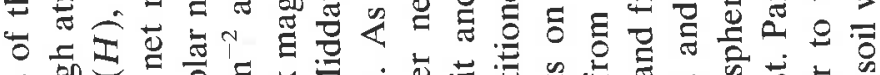

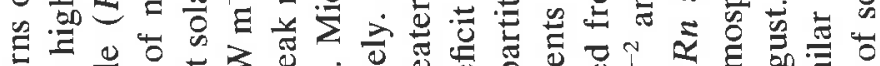

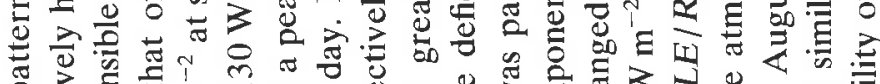

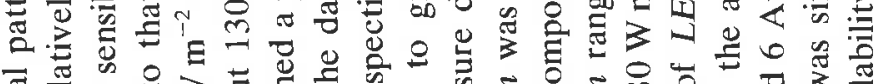

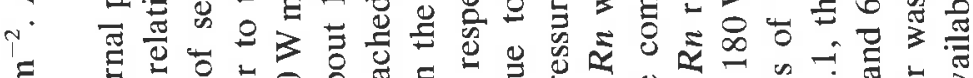
E.

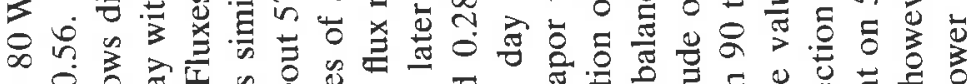

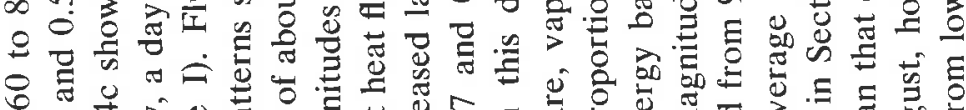

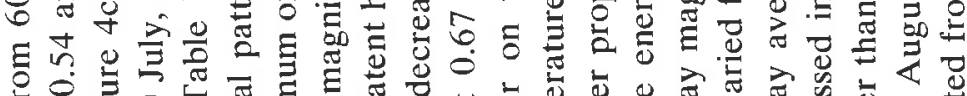

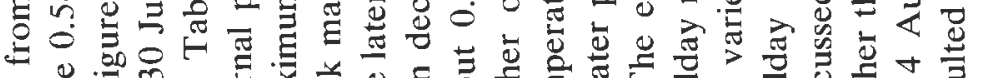

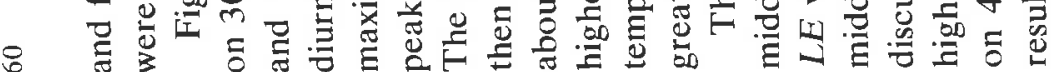

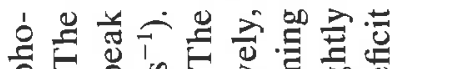

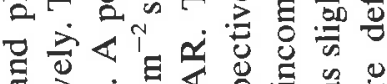

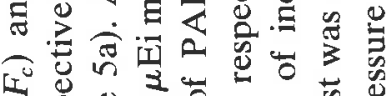

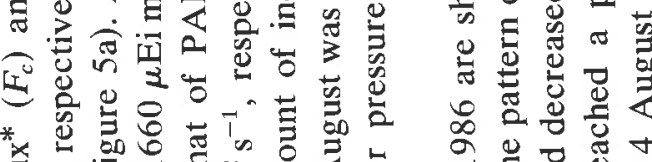

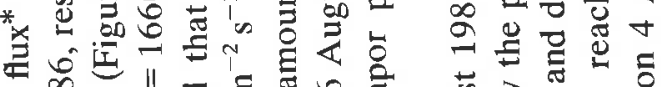

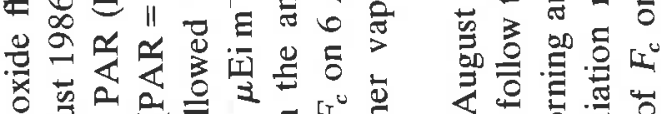

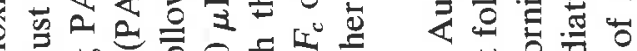
कo

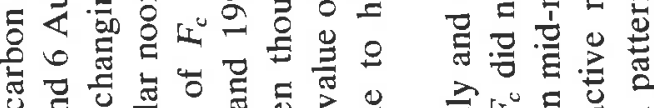

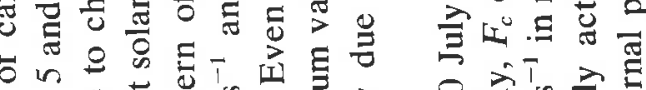

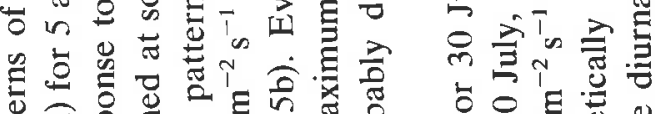

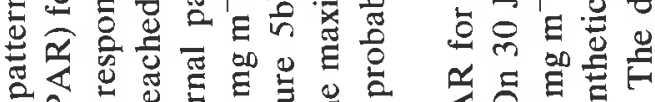

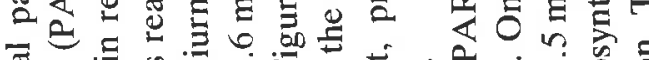
番

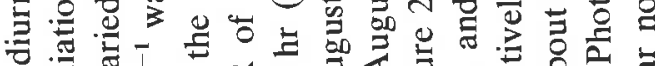
\%

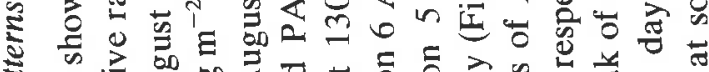

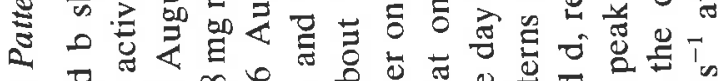

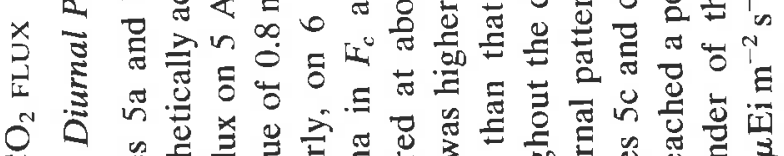
ウं 


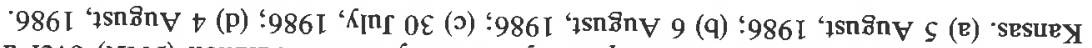

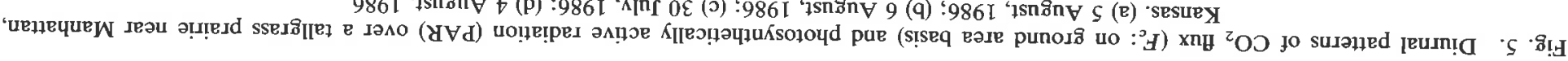
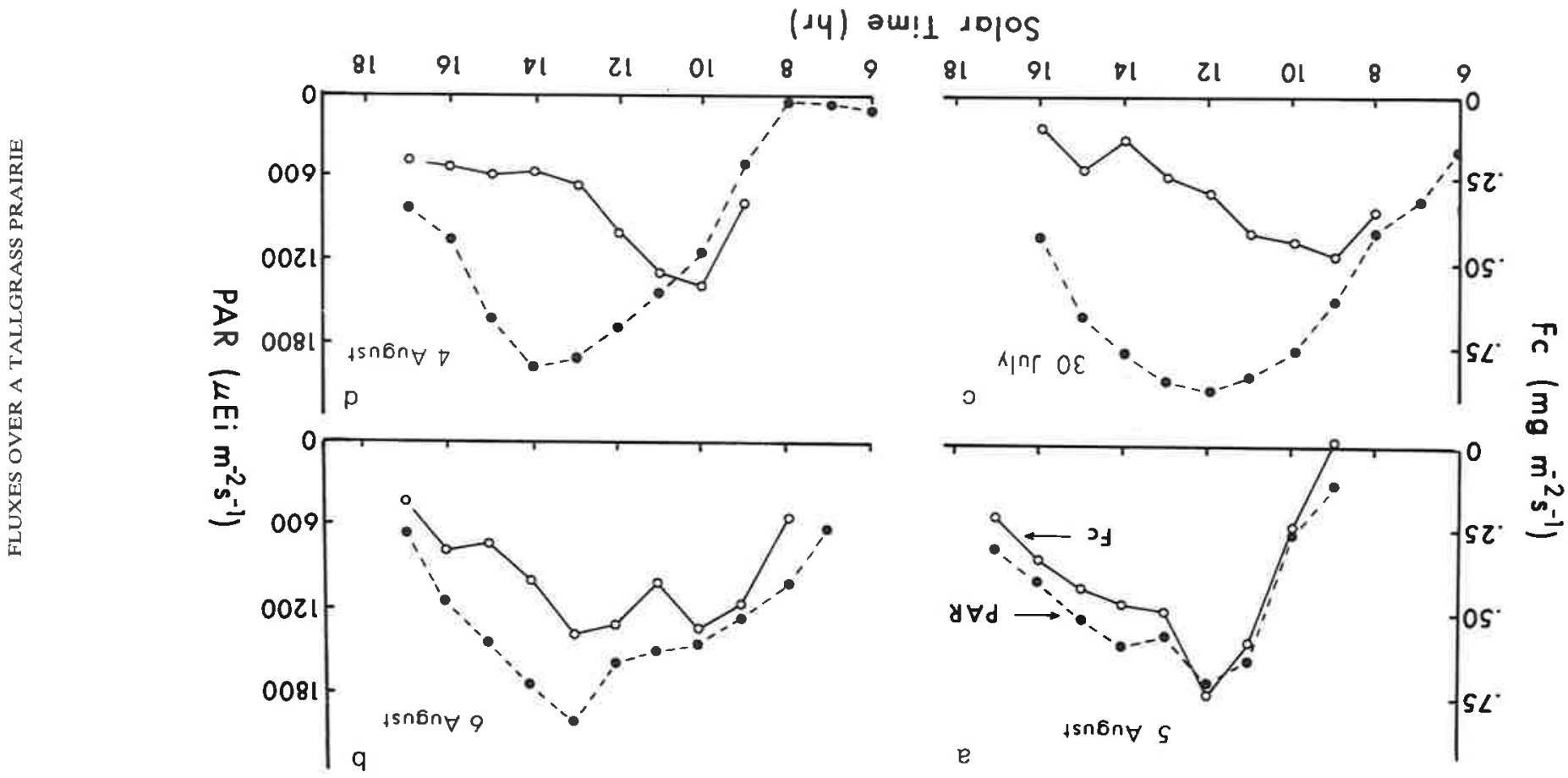

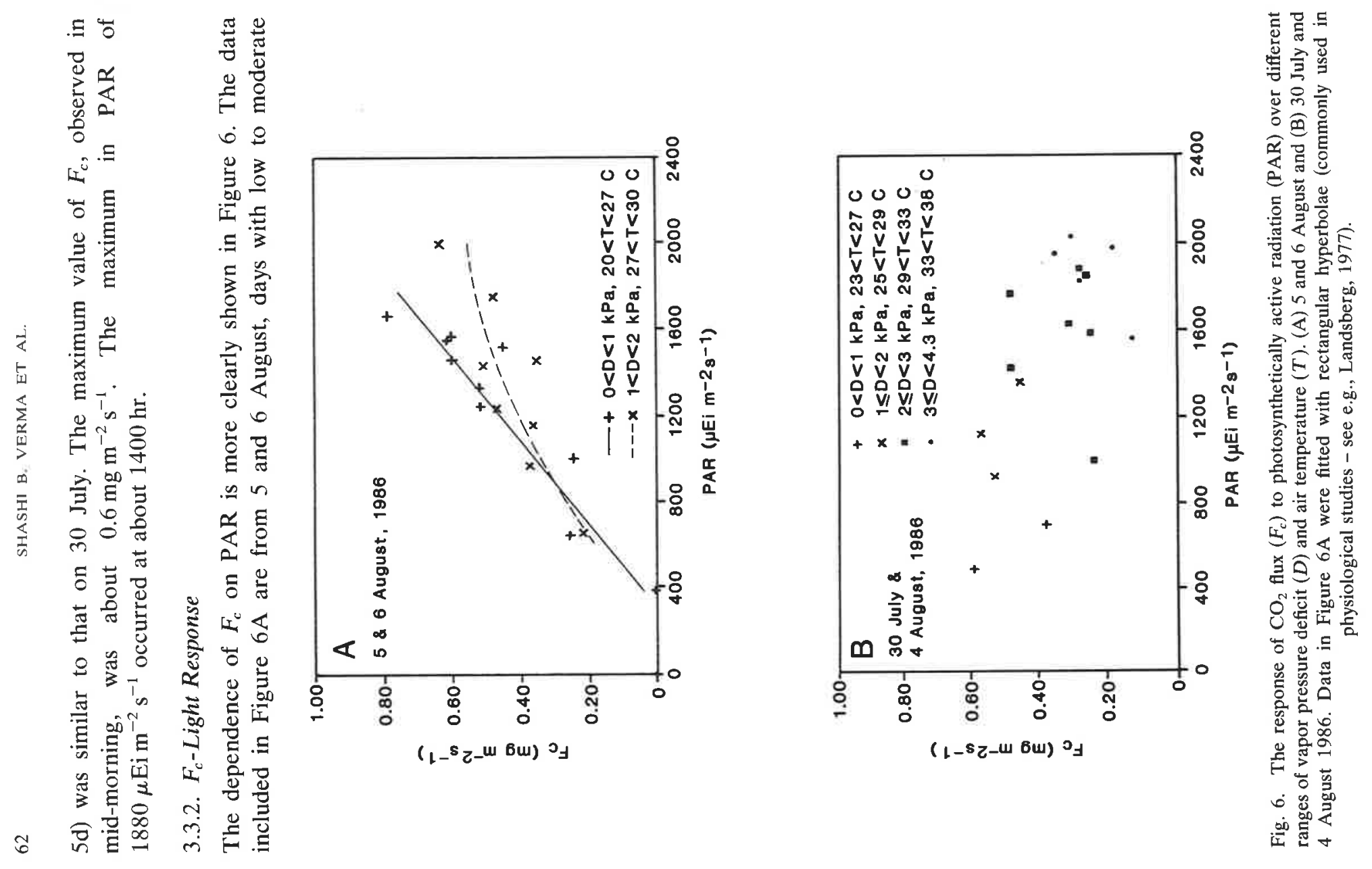


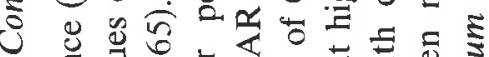

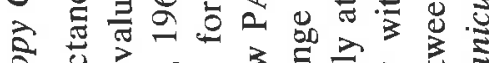

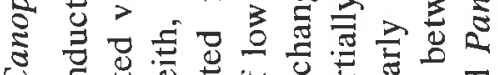
U.

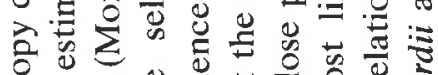

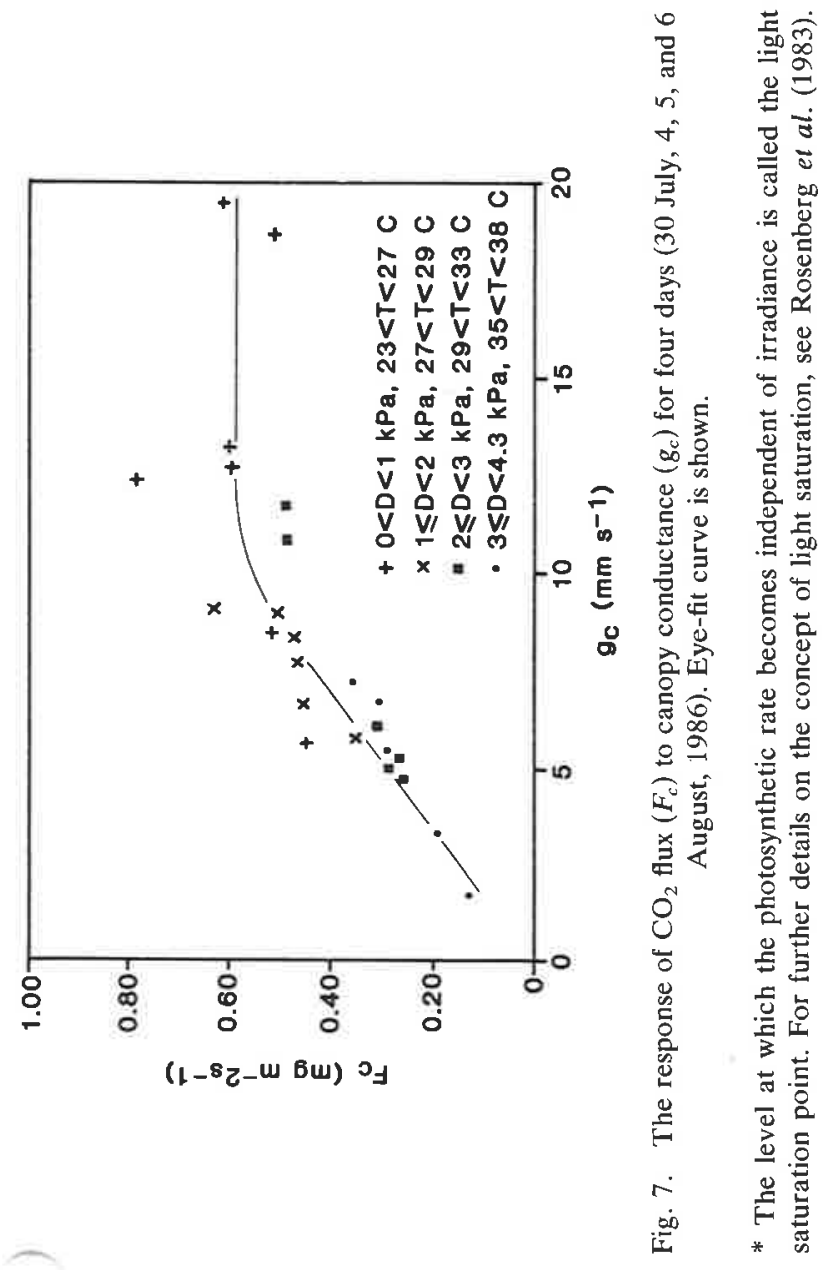




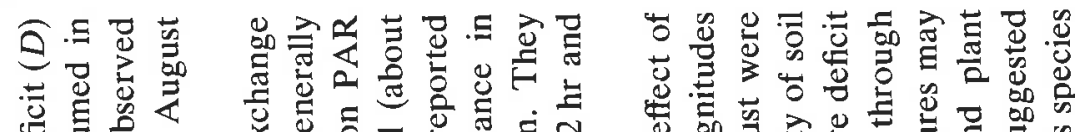

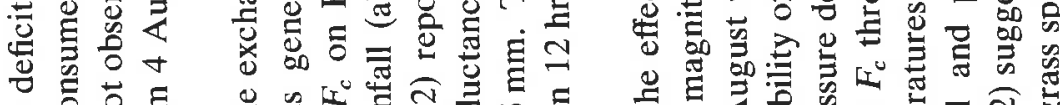

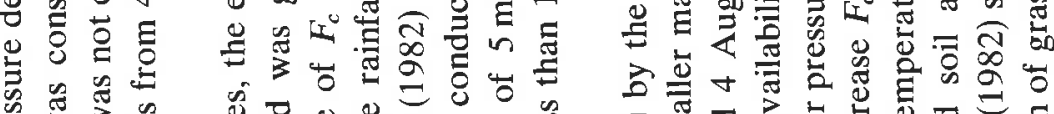

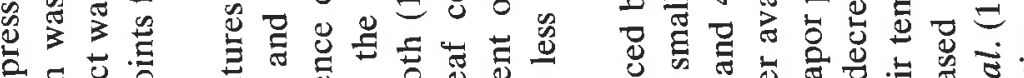

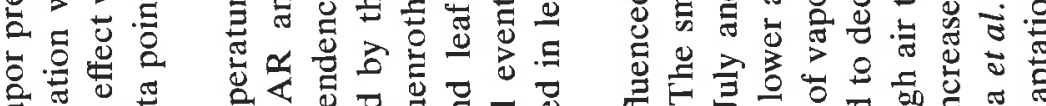
漹

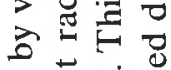

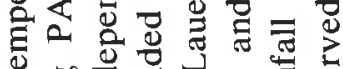
Q bo

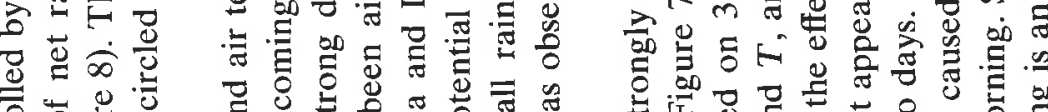

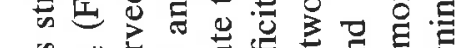

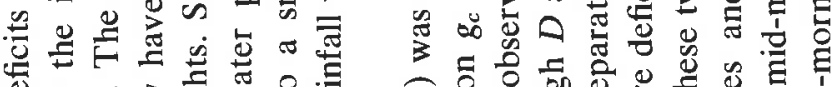

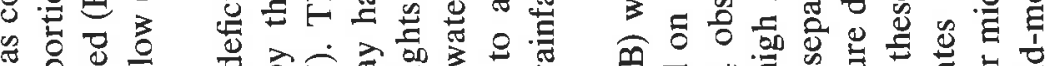

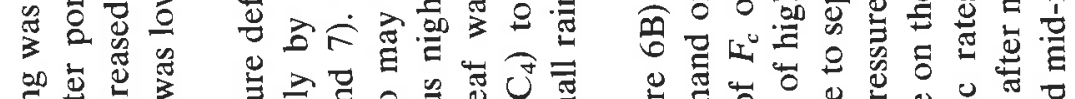

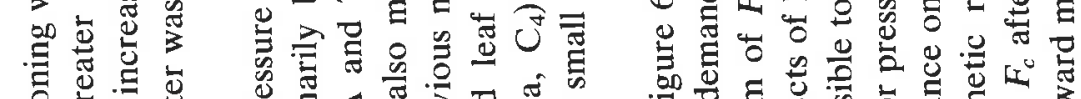

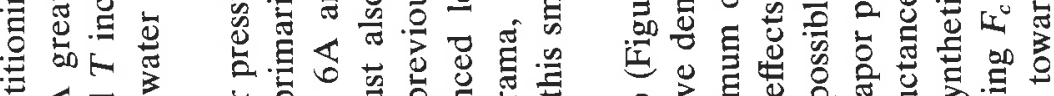

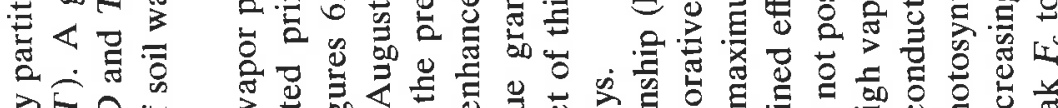
तิ

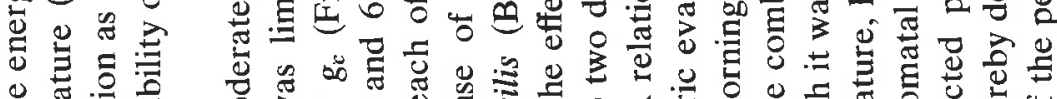

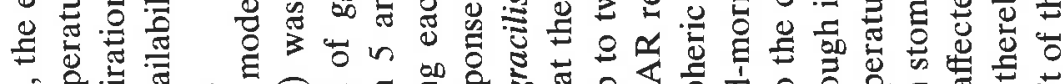

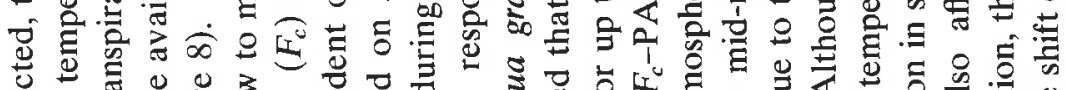

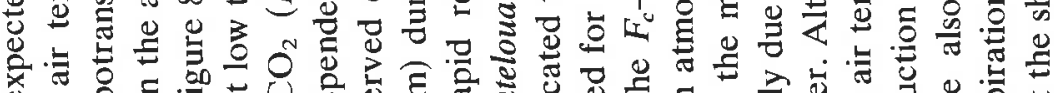

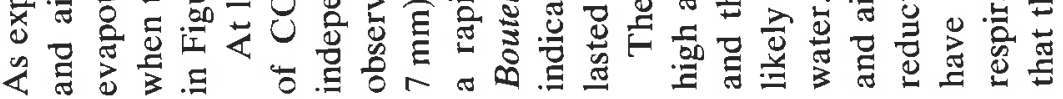

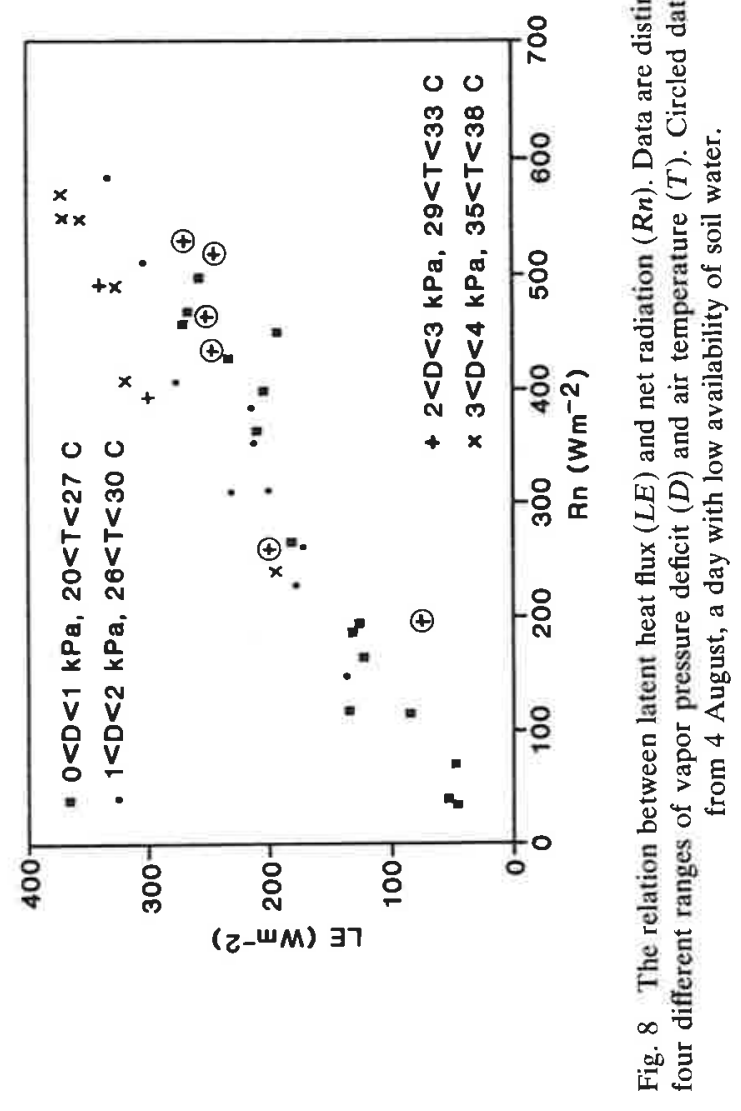




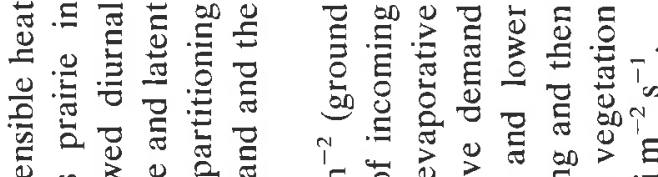

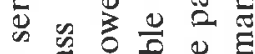

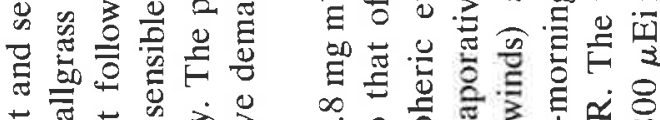

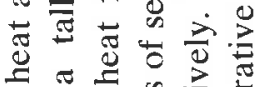

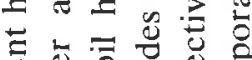

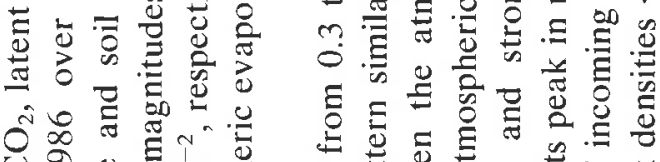

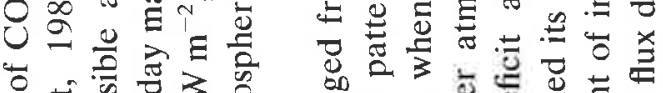

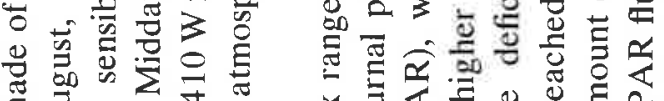

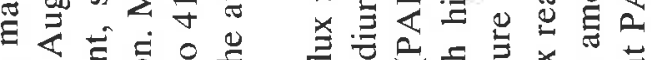

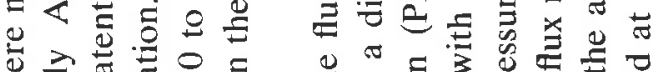

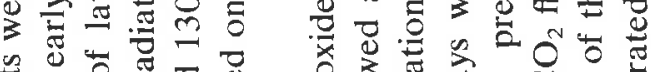

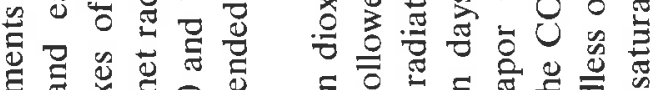

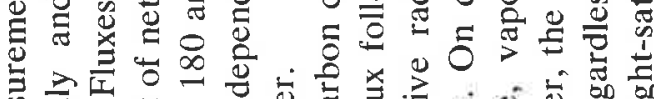

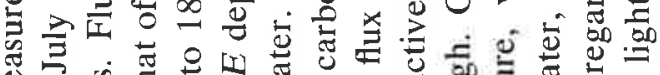

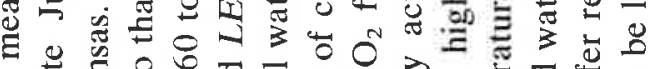

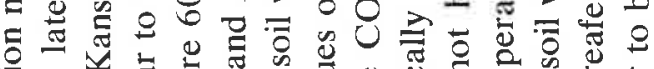

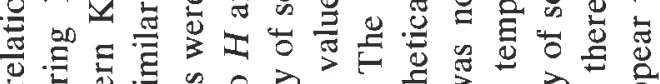

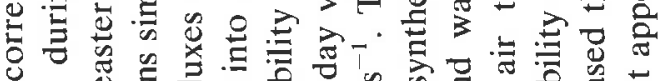

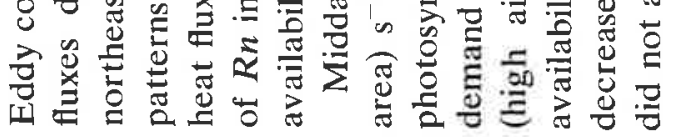

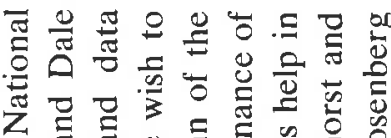

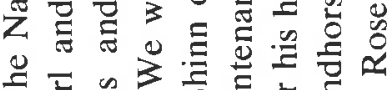

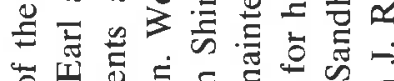

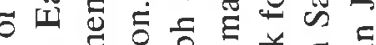

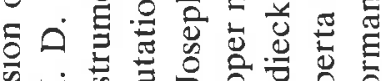

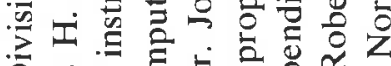

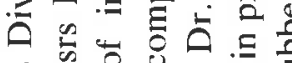

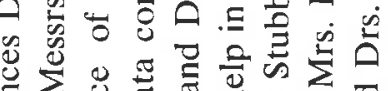

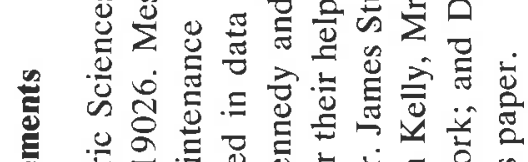

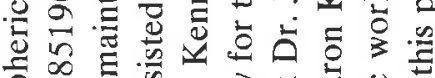

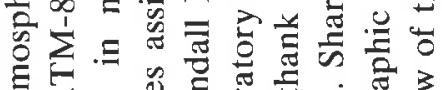

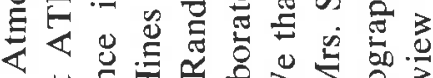

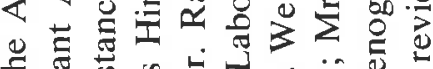

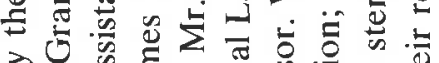

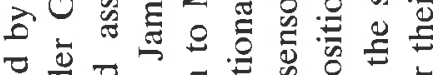

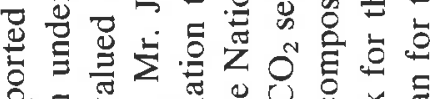

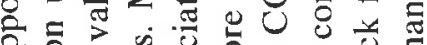

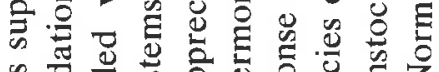

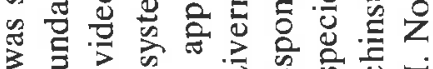
उ० 0 के

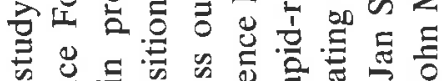

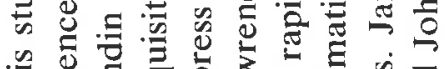

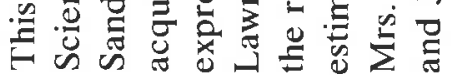




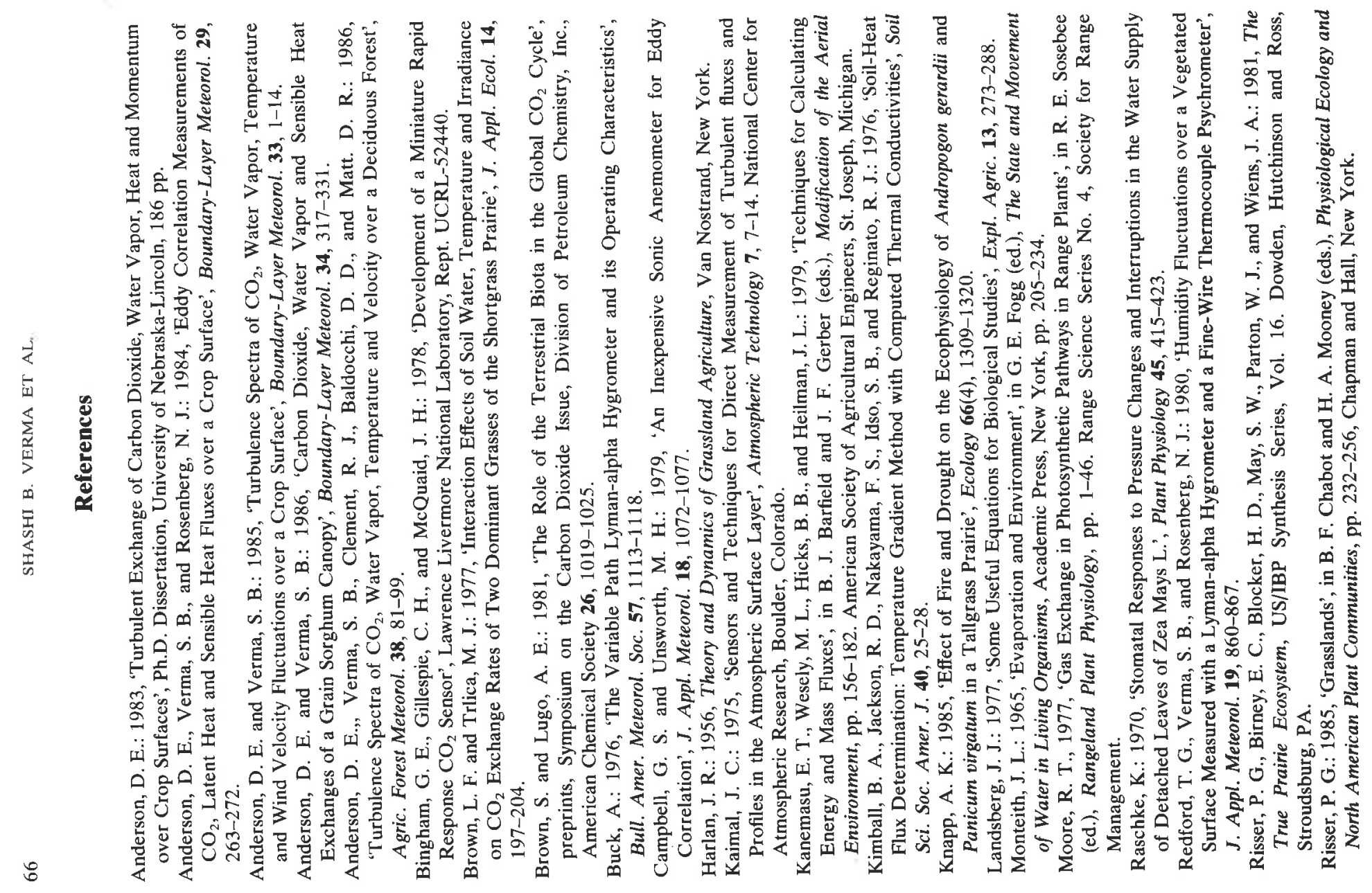




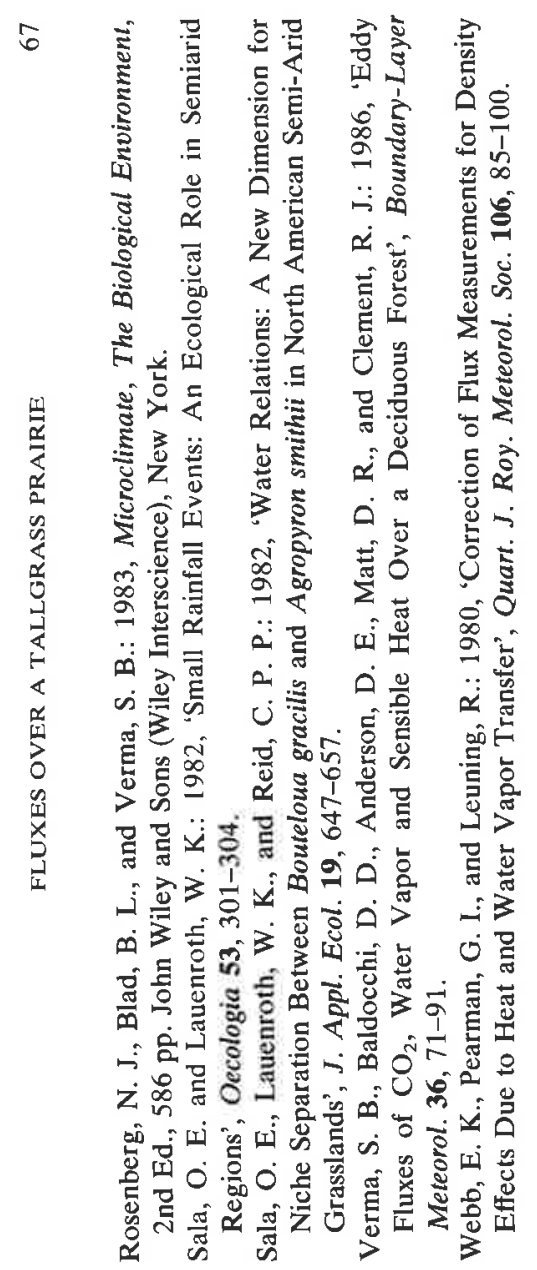


